\title{
Determinants of External Demand for Textiles and Garments of Sri Lanka
}

\author{
Niluka Ekanayake ${ }^{1 /}$
}

\begin{abstract}
This paper evaluates the determinants of export demand for textiles and garments of Sri Lanka, using quarterly data from 1999 to 2013. A long run relationship is found between export demand and explanatory variables. The empirical results reveal that the depreciation of the real exchange rate does not increase the demand for Sri Lanka's textiles and garments, as this industry is found to be heavily dependent on imported raw materials. World GDP which proxies the income of buyers is also a major determinant of export demand. It is also found that the GSP plus (Generalised System of Preferences-plus) and MFA (Multifiber Arrangement) had a positive and significant impact on the demand for textiles and garments of Sri Lanka as they provided duty free access to major textile and garment markets such as USA and EU particularly when the global financial crisis and debt crisis had a negative impact on world demand for textiles and garments. It is surprising to observe that trade openness which proxies the level of trade restrictions between Sri Lanka and the rest of the world shows a negative relationship with export demand for textiles and garments from Sri Lanka.
\end{abstract}

JEL Classification: C51, F14, F53

Key Words: External Demand, Textiles \& Garments, Co-integration, Export Volume, Error Correction Model, Vector Auto Regressions.

1/ I am grateful to Ms. Swarna Gunaratne, Dr. R A Perera, Dr. P K G Harischandra, Dr. H K J Ekanayake, Dr. R A Anil Perera and Ms. Dimuthu Samaratunga of the Central Bank of Sri Lanka for providing valuable comments and suggestions. I also thank Mr. H P G S Ratnasiri, Ms. T M U K Tennakoon and Mr. G T R Priyadarshana for their support and anonymous reviewers for their valuable comments.

Correspondence: niluka_p@cbsl.lk. 


\section{Introduction}

As one of the key drivers of Sri Lanka's economy, the export oriented textiles and garments industry has played a major role during the five decades of its existence. The history of ready-made garment exports can be traced back to the 1960s, where the first garment exports from Sri Lanka were to Russia. After 1977 under open economic policies, the export oriented ready-made garment industry grew at a rapid pace. Under the Multifibre Arrangement (MFA) $)^{2 /}$ quota regime which was active from 1974 till 1994 and the Agreement on Textiles and Clothing (ATC) $)^{3 /}$ which was active from 1995 till 2004 as a replacement for MFA, Sri Lanka became an attractive destination for the textiles and garments manufacturing. Owing to the investment incentives offered by the government, coupled with the low cost of production due to the availability of a highly skilled and trainable workforce at lower cost, a high level of foreign investments were attracted in to the export oriented garment industry. However, on January 1, 2005, the worldwide system of textile and apparel quotas was discontinued leading to a major shift in global trade and production trends. Industries in the textiles and clothing sector, which provide the backbone to many developing economies, were faced with many challenges afterwards as they had to operate in a quota free environment amidst intense competition and increasing cost of production. In 2005, the Generalized System of Preferences (GSP) plus system came into operation. The scheme had three core objectives, namely, poverty reduction, promoting sustainable development and promoting good governance. Fifteen countries including eleven Latin American countries, Moldova, Georgia, Mongolia and Sri Lanka benefited from the GSP plus scheme. Sri Lanka benefited much from the scheme as the GSP plus extended a greater proportion of concessions to readymade garments to enter into European Union (EU) market. This is evidenced as the readymade garment exports from Sri Lanka to EU increased from 36.2 per cent of total garment exports in 2005 to 48.8 per cent in 2008, while the share of Sri Lanka's readymade garment exports to USA decreased from 59.4 per cent in 2005 to 45.2 per cent in 2008 in the absence of the MFA. However, the removal of GSP plus in 2010 brought many challenges to Sri Lanka as the country had to compete with fourteen other GSP plus recipients who also obtained the duty free access to the EU market and other competitors such as India, who already had preferential and free trade agreements with the EU.

2/ An international trade agreement on textile and clothing that was active from 1974 till 1994. The agreement imposed quotas on the amount that developing countries could export in the form of yarn, fabric and clothing to developed countries. This provided for the application of selective quantitative restrictions when surges in imports of particular products caused, or threatened to cause, serious damage to the industry of the importing country.

3/ In 1995, the MFA was replaced by the WTO Agreement on Textiles and Clothing (ATC), which set out a 10 -year transitional process for removal of the quotas set under MFA. For this study, the abbreviation MFA is used to mean both the MFA and the ATC. 
As per available data, between 2005 and 2011, the value of global apparel exports rose by 48 per cent. In 2011, the value of global apparel exports were US dollars 412 billion. As per Aid for Trade and Value Chains in Textiles and Apparel (2013), the top ten developing countries' (Table 1) suppliers account for around 58 per cent of global apparel exports, with China taking 37 per cent of global apparel exports. Since 2000, China has topped the list of apparel exporters to the USA and EU. Sri Lanka has also joined the top fifteen apparel exporters to the USA since 1980 and EU since 2000 (Table 2 and Table 3).

Table 1 : Developing Country Suppliers and the Global Apparel Markets

\begin{tabular}{lcccc}
\hline Exporter & $\begin{array}{c}2005 \\
\text { USD Mn }\end{array}$ & $\begin{array}{c}2011 \\
\text { USD Mn }\end{array}$ & $\begin{array}{c}\text { Percentage change } \\
(2005-2011)\end{array}$ & $\begin{array}{c}\text { \% of total exports } \\
\text { in 2011 }\end{array}$ \\
\hline China & 74,162 & 153,773 & $107 \%$ & $37.00 \%$ \\
\hline Bangladesh & 6,889 & 19,938 & $189 \%$ & $4.80 \%$ \\
\hline India & 8,738 & 14,364 & $64 \%$ & $3.50 \%$ \\
\hline Turkey & 11,833 & 13,947 & $18 \%$ & $3.40 \%$ \\
\hline Viet Nam & 4,680 & 13,153 & $181 \%$ & $3.20 \%$ \\
\hline Indonesia & 4,958 & 8,045 & $63 \%$ & $1.90 \%$ \\
\hline Mexico & 7,305 & 4,637 & $-36 \%$ & $1.10 \%$ \\
\hline Malaysia & 2,478 & 4,567 & $84 \%$ & $1.10 \%$ \\
\hline Pakistan & 3,603 & 4,549 & $26 \%$ & $1.10 \%$ \\
\hline Cambodia & 2,210 & 4,050 & $83 \%$ & $1.00 \%$ \\
\hline World Total & 278,000 & 412,000 & $48 \%$ & \\
\hline
\end{tabular}

Source : WTO database

Table 2 : Top 15 Apparel Exporters to the United States

\begin{tabular}{|c|c|c|c|c|c|c|}
\hline Rank & 1970 & 1980 & 1990 & 2000 & 2008 & 2011 \\
\hline 1 & Japan & Hong Kong & Hong Kong & China & China & China \\
\hline 2 & Hong Kong & Other Asia & China & Mexico & Vietnam & Vietnam \\
\hline 3 & Other Asia & Korea & Korea & Hong Kong & Indonesia & Indonesia \\
\hline 4 & Korea & China & Other Asia & Korea & Mexico & Bangladesh \\
\hline 5 & Italy & Mexico & Philippines & Dominican Rep. & Bangladesh & Mexico \\
\hline 6 & Philippines & Philippines & Italy & Honduras & India & India \\
\hline 7 & Canada & Japan & Dominican Rep. & Indonesia & Honduras & Honduras \\
\hline 8 & United Kingdom & Italy & Mexico & Other Asia & Cambodia & Cambodia \\
\hline 9 & Mexico & India & India & Bangladesh & Thailand & Italy \\
\hline 10 & Israel & Singapore & Indonesia & Thailand & Italy & Thailand \\
\hline 11 & Germany & France & Singapore & India & Pakistan & Pakistan \\
\hline 12 & France & Macao & Malaysia & Philippines & Hong Kong & El Salvador \\
\hline 13 & Spain & Dominican Rep & Thailand & Canada & Sri Lanka & Malaysia \\
\hline 14 & Austria & Sri Lanka & Bangladesh & Italy & El Salvador & Sri Lanka \\
\hline 15 & Singapore & United Kingdom & Sri Lanka & El Salvador & Malaysia & Nicaragua \\
\hline
\end{tabular}

Source : Aid for Trade and Value Chains in Textiles and Apparel (2013) 
Table 3 : Top 15 Apparel Exporters to the European Union

\begin{tabular}{rllll}
\hline Rank & 2000 & 2004 & 2008 & 2011 \\
\hline 1 & China & China & China & China \\
\hline 2 & Turkey & Turkey & Turkey & Turkey \\
\hline 3 & Hong Kong & Bangladesh & Bangladesh & Bangladesh \\
\hline 4 & Tunisia & India & India & India \\
\hline 5 & Bangladesh & Tunisia & Tunisia & Tunisia \\
\hline 6 & India & Morocco & Morocco & Morocco \\
\hline 7 & Morocco & Hong Kong & Vietnam & Vietnam \\
\hline 8 & Indonesia & Indonesia & Indonesia & Pakistan \\
\hline 9 & Thailand & Pakistan & Sri Lanka & Sri Lanka \\
\hline 10 & Korea & Thailand & Pakistan & Indonesia \\
\hline 11 & Pakistan & Sri Lanka & Thailand & Thailand \\
\hline 12 & Sri Lanka & Vietnam & Hong Kong & Cambodia \\
\hline 13 & Vietnam & Korea & Switzerland & Malaysia \\
\hline 14 & Malaysia & Switzerland & Malaysia & Switzerland \\
\hline 15 & Mauritius & Malaysia & Cambodia & Macedonia \\
\hline
\end{tabular}

Source : Aid for Trade and Value Chains in Textiles and Apparel (2013)

The garment industry in Sri Lanka has become an important driver of the economy in terms of its contribution to industrial production, foreign exchange earnings and direct and indirect employment generation. Being the country's largest industry, it accounts for nearly 25 per cent of industrial production and 40 per cent of export earnings while generating nearly 300,000 of direct employment opportunities and nearly 600,000 of indirect employment opportunities. The USA and the EU are the largest destinations for garment exports of Sri Lanka, with the USA accounting for around 42 per cent of exports while the share of EU is around 46 per cent. However, a gradual improvement is observed in textiles and garment exports to other countries such as Canada, Japan, South Korea and China over the period showcasing the efforts taken by the industry for market diversification. Over the years, Sri Lanka's textiles and garments industry performed well and Sri Lanka's strength in textile and garment manufacturing lies in its ability to produce high quality garments at competitive prices, combined with an industry structure which is flexible and uniquely capable of servicing the leading international brands. By utilising specialised ethical production processes acquired by the industry to cater to niche markets, the textile and garment industry targets an increase in exports to more than US dollars 5 billion by 2015 .

The highly dynamic nature of the global apparel industry produces many challenges and opportunities such as frequently changing consumer preferences, the requirement of 
intermediaries in the industry, intense competition and new technology that have to be faced by the firms. As garments are closely related to fashion industry it is necessary to be flexible as well as be able to meet the deadlines of the buyers. Consumers have become extremely price and quality sensitive as they are offered lot of choices by competitors. As explained by Fonseka and Fonseka (2004), when making the purchasing decision buyers seek value for money. This includes design, neatness, and excellence of workmanship for the price.

Accordingly, identifying the determinants of external demand for textiles and garments would be useful for pricing and other related decision making. This research intends to estimate the determinants of external demand for textiles and garments of Sri Lanka.

The paper is structured as follows. Section 2 presents the facts about the textiles and garments industry in Sri Lanka, Section 3 reviews the findings of previous empirical studies while Section 4 describes the theoretical framework and model, Section 5 discusses the methodology and empirical results and Section 6 discusses the findings followed by the conclusion and policy recommendations in Section 7.

\section{Textiles and Garments Industry in Sri Lanka}

As individual countries, the USA and the UK have historically been the largest buyers of Sri Lankan apparel through the decades while the USA and the EU been the largest markets. Being the main foreign exchange earner, Sri Lanka's textiles and garments industry has faced many challenges and opportunities (Figure 1). However, it has emerged as a major driver of the economy.

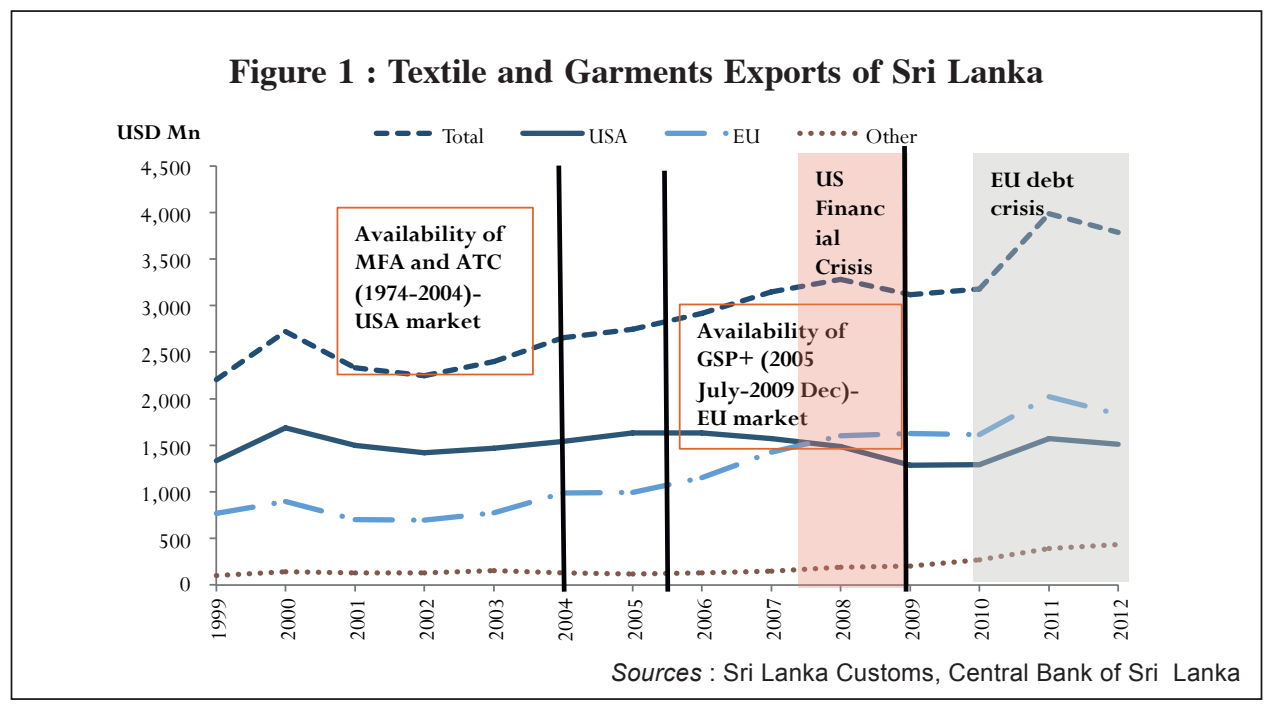


Figure 2 : Textiles and Garment Industry: Import Dependency Ratio (\%)

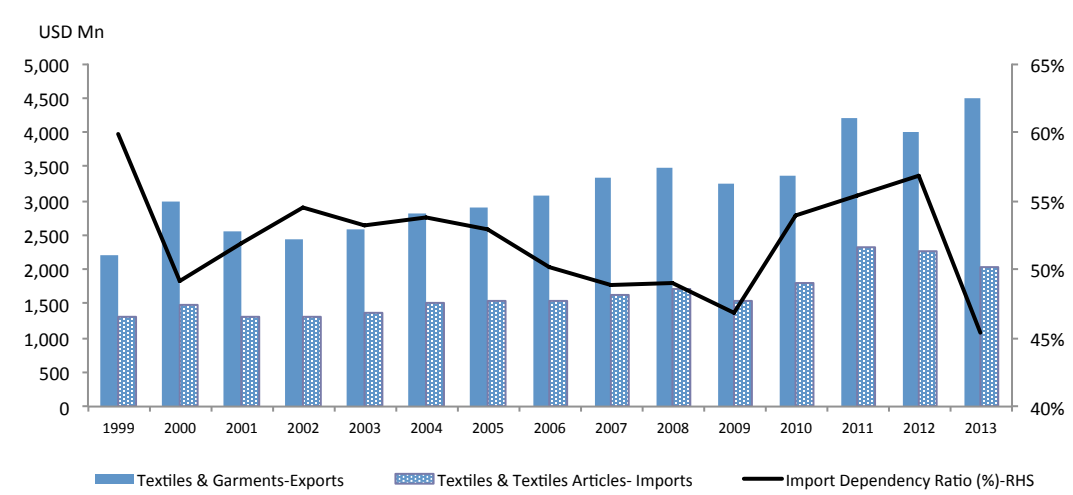

Sources : Sri Lanka Customs, Author's own calculations

Initially, Sri Lanka's garment industry was engaged in the assembling of garments. However, it has now moved towards positioning itself as a 'fashion' industry. The continuous investment on research and development coupled with the acquisition of expert knowledge has helped the industry to move to high quality, fashionable products. Traditionally, the garment industry was found to be heavily dependent on imported raw materials (Figure 2). However, having recognised the importance of backward integration, the industry is taking continuous efforts to reduce the import dependency ratio, thereby increasing the value addition of the industry through local production of raw materials.

Generally, the buyers placing garment orders have the choice of selecting fabric and accessories from any part of the world to be brought to Sri Lanka for conversion into finished apparel. Further, there is an advantage in sourcing garments from Sri Lanka due to its location, which provides the shortest shipping times to Europe. At present, Sri Lanka is producing garments for reputed international brands. However, most of these items are handled via buying offices. The maintenance of safety and other international standards with regard to labour has helped the textile and garment industry in Sri Lanka to face the strong competition in international markets. Apart from these, the availability of a highly literate and skilled workforce has contributed for the rapid development in the garment industry.

However, Sri Lanka's garment industry faces many challenges. The high cost of production led by the high labour cost is a major challenge for Sri Lanka's garment industry. High utility charges and transportation costs also had adversely affected the competitiveness of the industry. These difficulties have coupled with delays and inefficiencies in documentation preparation, processing and inland transportation and handling. 
Even though the industry has taken steps to improve backward integration, it is still at the initial levels. In order to be competitive in the fast growing and rapidly changing international fashion industry which has a very short life span, producers have to lower the lead time by lowering the procurement and production cycles. Hence backward integration would lower the procurement and production cycles by increasing domestic sourcing of fabrics and other accessories.

\section{Review of Literature}

The determinants of export demand, especially for small economies, have been extensively studied. Understanding these determinants is essential in policy decision making with regard to external trade. Even though, the literature is available at aggregate level examining the determinants of export demand, at the disaggregate level would give more insights into the formulation of policies. This paper contributes to the literature by adding empirical evidence of the determinants of export demand for Sri Lanka's key export, i.e., textiles and garments.

Several studies have estimated import and export functions to ascertain the determinants of exports and imports elasticities. In most of the studies, when formulating the export demand function, factors such as real income of foreign trading partner/s, price of exports (or relative price), nominal (or real) exchange rate, exchange rate volatility, population and dummy variables to represent structural changes were considered.

Moreover, many recent studies which focused on the export and import demand functions suggested that income is the principal determinant of exports and imports. In the study carried out by Haideret et al. (2011) estimating the import and export demand functions revealed that income is the principal determinant of foreign trade while exchange rate also plays a major role in determining the demand for exports and imports.

Similarly, Siddiqi et al. (2012) examined the determinants of export demand of textiles and the clothing sector of Pakistan using annual data for the period 1971-2009 using the Johansen and Juselius methodology of maximum likelihood cointegration technique. As discussed in their paper, world income is the major determinant of export demand for textiles and the clothing sector of Pakistan. Trade openness which is used as a proxy of trade restrictions is the second major determinant of export demand. Other variables such as the price of textiles in the export market and the exchange rate were also found to be significant determinants of export demand. 
In order to evaluate the prospects of a free trade area in the SAARC ${ }^{4 /}$ region by member nations, a study was carried out by Suhail and Sreejesh (2011) using a multiple regression model to analyse the export demand function. In this study, the impact of bilateral trade agreements on export performance of SAARC nations was analysed with special reference to the India-Sri Lanka bilateral free trade agreement. Accordingly, it was found that variables such as GDP and population were significant with positive coefficients while price was not a significant determinant of exports of India and Sri Lanka.

The impact of exchange rate volatility on the export quantity has also been analysed in the literature. As discussed in Clark et al. (2004), the volatility of exchange rate was found to have a negative impact on trade volumes. This was further studied by Jantarakolica and Chalermsook (2012) using panel data analysis comparing nine products in the textile and garment sector for the period from first quarter of 2000 to the first quarter of 2011. They found that in the case of Thailand, exports of textile and garment products were significantly influenced by the export price as well as the exchange rate. Accordingly, higher exchange rate volatility caused a decline in export volumes.

Hooy and Choong (2010) conducted a similar study to examine the impact of exchange rate volatility on export demand within SAARC members. Data on bilateral exports on a monthly basis from January 1980 to January 2010 for four members of SAARC (i.e., Bangladesh, India, Pakistan and Sri Lanka) for which data are available were analysed using a multivariate asymmetric CCC-GARCH model applying a bound testing approach on the standard trade model framework. The results showed that foreign income, real exchange rate and exchange rate volatility affected exports in the region. Further, it was found that real exchange rate volatility had a significant and negative impact on the export demand of most of the SAARC countries.

As empirical studies suggest for small economies like Sri Lanka and Bangladesh the export demand is price inelastic. According to Choudhury (2001), there is evidence that for small economies, the devaluation of the currency does not have a significant impact on the demand for exports. Therefore, the exchange rate itself did not influence the demand decisions thus requiring some non-price policies to stimulate external demand.

A summary of empirical evidence on export determinants is given in Appendix I.

4/ The South Asian Association for Regional Cooperation (SAARC) is an economic and political organization of eight countries in Southern Asia namely India, Bangladesh, Pakistan, Sri Lanka. Nepal, Maldives, Bhutan and Afghanistan. 


\section{Theoretical Framework and the Model}

As explained by Dornbusch (1988) and Hooper and Marquez (1993), there are two main determinants of export demand. The first is foreign income, which shows the purchasing power of the foreign buyer. This implies that an increase in real GDP of the importing country would increase the volume of exports. This is known as the income effect. The second major determinant is the relative price. The appreciation of the real exchange rate will cause domestic goods to become less competitive than foreign goods, thereby increasing imports while decreasing exports. This is referred to as the price effect. Apart from that, as explained in the literature, exchange rate fluctuations, level of trade restrictions and preferential arrangements on bilateral and regional basis, national attitude towards foreign goods, taste, quality and technology are other determinants of export demand. In order to identify the most representative set of explanatory variables which determine the external demand for textiles and garments of Sri Lanka, prior empirical studies were reviewed. This paper broadly followed the approach of Siddiqi et al. (2012) and Hooy and Choong (2010). Such determinates are export price, exchange rate, world real GDP/ world income, trade openness and the availability of preferential access to markets e.g. MFA (Multifibre Arrangement), GSP + (Generalised System of Preferences).

Although all these variables would better represent the external demand function for textiles and garments of Sri Lanka, as a result of the possibility of loss of degrees of freedom due to a higher number of variables with fewer numbers of observations, and considering the suitability and the relevance to the Sri Lankan economy, selected variables were used for this study: importing country's income, real exchange rate and level of trade restrictions are being used as independent variables whereas two dummy variables are introduced in order to accommodate the effect of major changes in the consumption pattern of buyers during the sample period if any. As Khan and Ross (1977) and Salas (1982) suggest, in modeling the export demand function, the log-linear specification is preferred to a liner function. Therefore, the log-linear specification is used in the study.

This study consists of quarterly data from the first quarter of 1999 to the first quarter of 2013. The dependent variable is the natural log of Sri Lanka's external quantity index (lndemand) for Textiles and Garments as a proxy for the external demand for textiles and garments. In order to incorporate the income effect on external demand, this study uses the $\log$ of world GDP $(\ln w g d p)$. As the real exchange rate represents Sri Lanka's competitiveness and as it captures the change in exchange rate, which is important for a highly imported input dependent industry, the study uses the log of quarterly average Real Effective Exchange Rate (REER 24 ${ }^{5 /}$ ) index (lnreer24). Further, trade openness

5/ REER 24 index is prepared by the Central Bank of Sri Lanka (CBSL) for 24 trading partners and competitor countries. The use of export price index in place of REER 24 does not change results of the study significantly. 
is used to proxy the level of trade restrictions between Sri Lanka with the rest of the world (Intopen). Trade openness is measured by the sum of total exports and imports as a percentage of gross domestic production of Sri Lanka. An increase in trade openness indicates a decrease in trade restrictions with the rest of the world. The effect of MFA and GSP+ on export demand for textiles and garments is captured by the dummy variable 1 (D1). Further, during the sample period, consumers were faced with some challenges such as the global financial crisis and debt crisis. Dummy variable 2 (D2) is presented to capture the changes in consumption pattern due to such challenges. Data sources and data descriptions are given in Appendix II).

The study uses the following export demand function incorporating the factors described above:

$$
\text { Indemand }_{t}=\alpha+\beta_{1} \operatorname{lnwg} d p+\beta_{2} \text { lnreer } 24+\beta_{3} \text { lntopen }+\beta_{4} D 1+\beta_{5} D 2+\varepsilon_{t}
$$

where,

$$
\begin{aligned}
\alpha & =\text { constant } \\
\operatorname{lnwgdp} & =\text { Natural log of world GDP } \\
\text { lnreer } 24 & =\text { Natural log of Real Effective Exchange Rate index (REER, }(2010=100) \text { ) } \\
\text { lntopen } & =\text { Natural log of trade openness } \\
D 1 & =\text { a dummy variable to capture the effect of MFA and GSP+ } \\
D 2 & =\text { a dummy variable to capture the effect of financial crisis and debt crisis } \\
\varepsilon & =\text { error term }
\end{aligned}
$$

An increase in income level of buyers is expected to increase the real demand for goods and services due to the improvement in purchasing power. Hence, a positive relationship is expected between world income and quantity demanded for textiles and garments. As explained by Haider et al. (2011), the real effective exchange rate is used as an indicator of the country's external competitiveness, where an appreciation of REER indicates loss of competitiveness while a depreciation of REER indicates an increase in the competitiveness. Therefore, the expected sign of the coefficient of the real effective exchange rate is negative. Trade openness is used as a proxy for the trade restrictions. An increase in trade openness indicates a reduction in trade restrictions between Sri Lanka and the rest of the world. Therefore, a positive relationship is expected between trade openness and the quantity of external demand for textiles and garments. The dummy variable 1 $(D 1)$ is expected to have a positive coefficient as the availability of MFA or GSP+ would certainly enhance the competitiveness of Sri Lanka's textiles and garments resulting in an increase of trade volume. Dummy variable 2 is expected to have a negative impact on the real income of foreign countries and thus on external demand. 


\section{Econometric Methodology and Empirical Results}

Several methods have been proposed for testing co-integration in the literature. As explained in Siddiqi et al. (2012), Johansen and Juselius multivariate analysis is more appropriate in determining demand factors when prices are endogenously determined. Further, as explained by Kalyoncu and Huseyin (2006), when the study involves more than two variables, the Johansen and Juselius method of co-integration analysis provides more robust results.

The time series properties of the economic variables were examined using unit root tests such as the Augmented Dickey-Fuller (ADF) test and Phillips-Perron (PP) test. Since the data is quarterly, lags up to 4 are included for correction of autocorrelation as proposed by the Akaike Information Criteria (AIC). These unit root tests are performed on both level and first differences. Summary results of the ADF test and PP test are given in Table 4 below.

Table 4 : Results of Unit Root Test

\begin{tabular}{|c|c|c|c|c|c|}
\hline \multirow{2}{*}{ Variable } & \multirow{2}{*}{ Indicator } & \multicolumn{2}{|c|}{ ADF } & \multicolumn{2}{c|}{ PP } \\
\cline { 3 - 6 } & & Level & 1st Difference & Level & 1st Difference \\
\hline \multirow{3}{*}{ Indemand } & Statistic & -1.4741 & -7.2686 & -10.1277 & -74.1405 \\
\cline { 2 - 6 } & P-Value & 0.5389 & 0.0000 & 0.0000 & 0.0001 \\
\hline \multirow{2}{*}{ Inreer24 } & Statistic & -0.3271 & -5.8649 & -0.5620 & -5.8897 \\
\cline { 2 - 6 } & P-Value & 0.9137 & 0.0000 & 0.8703 & 0.0000 \\
\hline \multirow{2}{*}{ Inwgdp } & Statistic & -1.4395 & -4.1708 & -1.7142 & -4.1344 \\
\cline { 2 - 6 } & P-Value & 0.5564 & 0.0017 & 0.4187 & 0.0019 \\
\hline \multirow{2}{*}{ Intopen } & Statistic & -2.7967 & -4.5880 & -2.8155 & -19.8144 \\
\cline { 2 - 6 } & P-Value & 0.2050 & 0.0029 & 0.0625 & 0.0001 \\
\hline \multirow{2}{*}{$D 1$} & Statistic & -1.6841 & -7.2313 & -1.4900 & -8.2713 \\
\cline { 2 - 6 } & P-Value & 0.4337 & 0.0000 & 0.5314 & 0.0000 \\
\hline \multirow{2}{*}{$D 2$} & Statistic & -0.8640 & -7.4162 & -0.8640 & -7.4162 \\
\cline { 2 - 6 } & P-Value & 0.7924 & 0.0000 & 0.7924 & 0.0000 \\
\hline
\end{tabular}

At levels, the null hypothesis of "the series has a unit root" is failed to reject at $5 \%$ significant level. Accordingly, all the variables are non-stationary at levels or all these variables are $\mathrm{I}(1)$ variables.

As empirical evidence suggests, a Johansen (1995) multivariate co-integration analysis is carried out to check whether these I(1) variables are co-integrated in the long-run. 
Table 5 : Co-integration Test Results

\begin{tabular}{ccccc}
\hline Null Hypothesis & $\boldsymbol{\lambda}$-Trace & $\begin{array}{c}\boldsymbol{\lambda} \text {-Trace 5\% Critical } \\
\text { Value }\end{array}$ & $\boldsymbol{\lambda}$ - Max & $\begin{array}{c}\boldsymbol{\lambda} \text { - Max 5\% Critical } \\
\text { Value }\end{array}$ \\
\hline$r=0$ & 105.74 & 95.75 & 42.86 & 40.08 \\
$r \leq 1$ & 62.89 & 69.82 & 25.15 & 33.88 \\
\hline
\end{tabular}

As per the results shown above (Table 5), both the Trace statistics and Maximum Eigenvalue statistics confirm the existence of one co-integrating vector between the variables. Once the existence of one co-integrating relationship is established, the next step is to estimate the Error Correction Model to identify the normalised co-integrating coefficients with respect to export demand of textiles and garments. Table 6 shows the results of the Error Correction Model.

Table 6 : Normalised Co-integrating Coefficients

\begin{tabular}{lcccccc}
\hline & Indemand & Inwgdp & Inreer24 & Intopen & D1 & D2 \\
\hline$\beta$ Coefficient & 1 & -0.3926 & -0.9962 & 0.5498 & -0.2590 & 0.1157 \\
Standard Errors & & 0.1884 & 0.3130 & 0.1793 & 0.0660 & 0.0882 \\
T-Statistics & & $-2.0836^{*}$ & $-3.1828^{*}$ & $3.0660^{*}$ & $-3.9255^{*}$ & 1.3120 \\
\hline
\end{tabular}

* Significant at $5 \%$ level

Accordingly, the t-statistics confirm that, $\ln w g d p$ (world GDP), lnreer24 (REER 24 index), Intopen (trade openness with rest of the world) and D1 (GSP+ and MFA) are significant at $5 \%$ level. As per the results, the expected signs of variables other than REER (lnreer 24 ) and trade openness hold true. However, as these two variables are significant at $5 \%$ level, it could not be dropped from the model.

Table 7 : Error Correction Model

\begin{tabular}{lcccccc}
\hline & $\mathbf{D}($ Indemand) & $\mathbf{D}$ (Inwgdp) & $\mathbf{D}$ (Inreer24) & $\mathbf{D}$ (Intopen) & $\mathbf{D}(\mathbf{D} 1)$ & $\mathbf{D}(\mathbf{D 2})$ \\
\hline a Coefficient & -0.4916 & 0.0053 & 0.0312 & -0.3023 & 0.8271 & -0.1685 \\
Standard Errors & 0.1498 & 0.0111 & 0.0485 & 0.1741 & 0.3845 & 0.2620 \\
T-Statistics & $-3.2817^{*}$ & 0.4760 & 0.6427 & -1.7361 & $2.1510^{*}$ & -0.6431 \\
\hline
\end{tabular}

* Significant at $5 \%$ level

The coefficient of Error Correction Term of $\mathrm{D}$ (Indemand) as shown above, is -0.4916 . This indicates that $49 \%$ of the deviation from the equilibrium is corrected within a quarter, taking around 2 quarters to reach the equilibrium. 
Accordingly, the determinants of external demand for Sri Lanka's Textiles and Garments can be specified as follows:

$$
\text { lndemand }_{t}=1.44+0.39 \text { lnwgdp }+0.99 \text { lnreer } 24-0.55 \text { lntopen }+0.26 D 1-0.12 D 2
$$

As per the estimated equation above, a 1 per cent increase in the real GDP of buyers would increase the export demand for Sri Lanka's textiles and garments by 0.39 per cent, while a 1 per cent appreciation (increase) in REER would increase the export demand for textiles and garments by 0.99 per cent and demand for textiles and garments will decline by 0.55 per cent when trade openness is increased by 1 per cent. As shown by the findings, MFA and GSP+ had a positive effect of 0.26 per cent on demand. The occurrence of financial and debt crisis had a negative effect of 0.12 per cent on the demand for textiles and garments of Sri Lanka in the world market.

The residual tests were carried out for the model and it was found that the model is free from autocorrelation and heteroskedasticity. Results of alternative models which were carried out to check the robustness of the study is given in the Appendix III. As an alternative to REER 24, export price index for textiles and garments was used in the alternative analyses. Accordingly, it is also found that the income of foreign buyers has a positive and significant impact on the demand for textiles and garments while price of textiles and garments has a negative and significant impact. Trade openness shows a negative relationship with the demand for textiles and garments in all three alternative analyses.

\section{Discussion of Findings}

Findings of the study confirm that the variables, income of foreign buyers and availability of preferential arrangements such as MFA and GSP+ have a positive effect on the external demand for textile and garments as expected. The results indicate that the income elasticity of world demand for Sri Lanka's textiles and garments is 0.39 per cent. Similar results were found in previous studies, for instance, Hooy and Choong (2010) which estimates the export demand of SAARC economies for the sample period 1980-2010 reports 0.26 per cent of average income elasticity of export demand. However, the trade openness and REER 24 have an opposite impact on demand to what is expected. Therefore, it is necessary to examine the causes for such results and to examine whether it is true in real circumstances. When the facts are analysed, as shown in figure 3, it is evident that both total exports and imports increased during the period under consideration, showing increasing integration with the rest of the world. However, trade openness measured as a percentage of GDP is decreasing due to the fact that, the GDP of Sri Lanka has risen 
more than the increase in international trade. As the results of the study suggest, trade openness has decreased during the period under consideration even though the demand for textiles and garments increased showing a negative relationship. However, since the liberalization of the economy in 1977, trade restrictions have been removed gradually and the tariff structure also has been simplified. Hence, the decline in trade openness since 2005, (as shown in figure 3), could be due to the change in the development strategy of the government which has placed more emphasis on infrastructure development and import substitution.

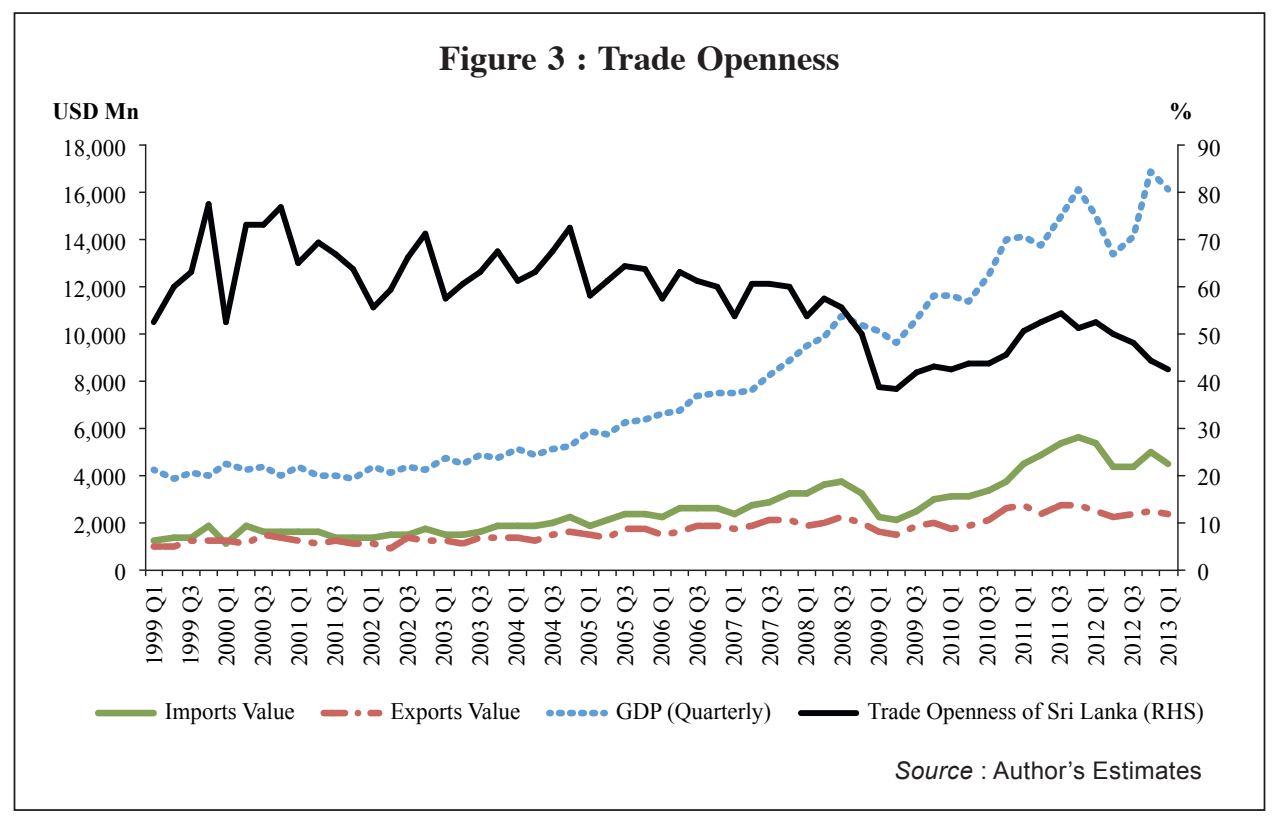

When analysing the reasons for the change in expected sign in REER 24 in the model, several reasons were found as described in empirical studies. As explained in Alam (2010) there was no causality from real depreciation of the Taka to export earnings of Bangladesh. Further, he explains that the depreciation of currency may coincide with greater exchange rate volatility and uncertainty and such uncertainty may have an adverse impact on exports. Telak and Yeok's (1998) findings may have more relevance for small economies whose exports are highly dependent on imported raw materials and intermediate inputs. The study uses Singapore data and finds that due to high import content, exports are not adversely affected by currency appreciation as the lower import price due to appreciation reduces the production cost of exports. Further, they have highlighted the importance of analysing the negative impact of depreciation on other sectors of the economy before 
taking any policy that helps depreciation. Dozovic and Pripuzic (2013) found that real effective exchange rates reflect the development of the relative price of the economy and hence they only relate to one aspect of international competitiveness and that does not capture all relevant aspects. Further, they state that as the REER is based on aggregate indicators like aggregate price or cost indices, it neglects differences that can exist between industries. They suggested using REER indices at industry level which is based on trade weights calculated at industry level and corresponding producer price indices, in order to reflect price competitiveness of particular industry more realistically. Therefore, as found in the analysis, the positive relationship between the real effective exchange rate and the export demand for textiles and garments of Sri Lanka could be due to a collective outcome of all these factors. Accordingly, appreciation in the real exchange rate of the Sri Lanka rupee has not dampened the demand for textiles and garments in international markets.

\section{Conclusion and Policy Implications}

As in many developing countries, the export oriented textile and garment industry is found to be one of the main drivers of the economy of Sri Lanka. The garment industry in Sri Lanka has become an important industry of the economy in terms of its contribution to industrial production, foreign exchange earnings and direct and indirect employment generation. Hence, identification of the determinants of external demand for textiles and garments is important both for the industry as well as policy makers.

This study attempts to identify the determinants of external demand for textiles and garments in international markets. According to the empirical findings, external demand of textiles and garments in the international market was determined by GDP of importing countries, appreciation/depreciation in exchange rate and trade openness with the rest of the world.

As in many studies in the literature, income of foreign buyers has a significant impact on the demand for textiles and garments. However, this study finds that the appreciation of exchange rate does not have a negative impact on the demand for textiles and garments. This could be due to the high dependency of the textile and garment industry of Sri Lanka on imported inputs, on average which is around 45 per cent. Therefore, it is evident that the depreciation of the exchange rate does not bring the expected favourable benefit in enhancing exports of textiles and garments. It suggests the importance of non-price factors such as innovation and quality improvements that may have an influence on the decisions of foreign buyers of textiles and garments. Further, as supported by the findings, the availability of the MFA and GSP+ had a positive and significant effect on the demand for Sri Lanka's textiles and garments in the international market as Sri Lanka enjoyed duty 
free access to the main markets. During the financial and debt crisis, external demand for Sri Lanka's textiles and garments had dampened due to the liquidity shortage and lower spending capacity of the buyers.

Accordingly, for the betterment of the textiles and garments industry of Sri Lanka several initiatives could be recommended. Among such initiatives, product diversification through vertical integration which will broaden the product base, market diversification to reduce the dependency on key markets thereby minimising concentration risk could be considered as important factors. Further, with the maturity of the industry, import dependency for raw materials could be reduced through backward integration where inputs are produced domestically. Other measures such as enhancing efficiency and reducing the lead time in delivery through improving the processes at ports and airports should be emphasised. Further, innovation through research and development for technological enhancements could also be considered as important. 


\section{References}

Abeysinghe, T., and Yeok, T.L. (1998). Exchange Rate Appreciation and Export Competitiveness. The case of Singapore. Internet Slide. http//courses.nus.edu.sg.

Alam, R. (2010). The Link between Real Exchange Rate and Export Earnings: A Cointegration and Granger Causality Analysis on Bangladesh, International Review of Business Research Papers, 205-214.

Andriamananjara, S., Balistreri, E., and Ross, M. T. (2006). State-Level Equity and the Demise of the Agreement on Textiles and Clothing. North American Journal of Economics and Finance, 17, 17-33.

Camarero, M., and Tamarit, C. (2003). Estimating Export and Import Demand for Manufactured Goods. The Role of FDI.

Choudhry, R.Z. (2001). Export Demand Function of Bangladesh.

Clark, P., Tamirisa, N., Wei, S., with Sadikov, A., and Zeng, L. (2004). Exchange Rate Volatility and Trade Flows - Some New Evidence, International Monetary Fund.

Dozovic, E., Pripuzic, D.I. (2010). Industry Specific Real Effective Exchange Rates in Central and Eastern European Countries.

Fonseka, T., and Fonseka, D. (2004). Competitive Strength of the Garment Industry, Ready-Made Garment Industry in Sri Lanka: Facing the Global Challenge, 47-76.

Haider, J., Afzal, M, Riaz, F. (2011). Estimation of Import and Export Demand Functions using Bilateral Trade Data: The case of Pakistan, Business and Economic Horizons, $40-53$.

Hooy, C., and Choong, C. (2010). Export Demand within SAARC Members: Does Exchange Rate Volatility Matter? International Journal of Economics and Management 4(2), 373-390.

Jantarakolica, T., Chalermsook, P. (2012). Thai Export under Exchange Rate Volatility: A Case Study of Textiles and Garment Products, Procedia-Social and Behaviroal Sciences 40, 751-755.

Kalyoncu, H. (2006). An Aggregate Import Demand Function for Turkey: A Cointegration Analysis, Munich Personal RePEc Archive, 4260. 
OECD/WTO/IDE-JETRO (2013). Aid for Trade and Value Chains in Textiles \& Apparel, World Trade Organization and OECD.

Riaz, F., and Afzal, M. (2011). Financial Factors in Capital Structure Decisions: Panel Data Analysis of Pakistan's Major Manufacturing Sectors, Interdisciplinary Journal of Contemporary Research in Business, Vol. 3, No. 1.

Sera, F., Pointon, J., and Abdon, H. (2011). Influencing the Propensity to Export: A Study of UK.

Siddiqi, W., Ahmad, N., Khan, A. A., and Yousef, K. (2012). Determinants of Export Demand of Textiles and Clothing Sector of Pakistan: An Empirical Analysis, World Applied Sciences Journal 16(8):1171-1175.

Suhail, P., Sreejesh, S. (2011). The Bilateral Trade Agreements and Export Performance of South Asian Nations with Special Reference to India Sri Lanka Free Trade Agreement, The Romanian Economic Journal, 115-128.

Telak and Yeok's (1998). Exchange Rate Appreciation and Export Competitiveness. The case of Singapore, Applied Economics, 1998, 30, $51 Đ 55$. 


\section{Appendix I : Summary of the Empirical Evidence}

\begin{tabular}{|c|c|c|c|}
\hline Authors & Scope & Methodology & Key Findings \\
\hline $\begin{array}{l}\text { Jahanzaib Haider, } \\
\text { Muhammad Afzal } \\
\text { and Farah Riaz } \\
\text { (2011) }\end{array}$ & $\begin{array}{l}\text { Annual data of Pakistan with all the } \\
\text { trading partners from } 1973 \text { to } 2008 \\
\text { for the following variables- } \\
\text { i. imports and exports } \\
\text { ii. real GDP } \\
\text { iii. CPI } \\
\text { iv. Bilateral exchange rate of } \\
\text { Pakistan with ten trading } \\
\text { partners }\end{array}$ & $\begin{array}{l}\text { Johansen technique to } \\
\text { test long run relationship } \\
\text { The lag order of VAR } \\
\text { is determined by (SIC) } \\
\text { Schwarz Information } \\
\text { Criterion, (FPE) Final } \\
\text { prediction Error and } \\
\text { AIC (Akaike Information } \\
\text { Criterion) for both import } \\
\text { and export models. }\end{array}$ & $\begin{array}{l}\text { The results revealed } \\
\text { that income is the } \\
\text { principle determinant } \\
\text { of foreign trade while } \\
\text { exchange rate also } \\
\text { plays a major role } \\
\text { in determining the } \\
\text { demand for exports } \\
\text { and imports (Pakistan) }\end{array}$ \\
\hline $\begin{array}{l}\text { Wasif Siddiqi, Nawaz } \\
\text { Ahmed, Abdul Aziz } \\
\text { Khan and Kamran } \\
\text { Yousef (2012) }\end{array}$ & $\begin{array}{l}\text { Annual data from } 1971-2009 \text { for the } \\
\text { following variables } \\
\text { i. Export volume is used as } \\
\text { export demand. } \\
\text { ii. Consumer price index of } \\
\text { textiles and clothing sector of } \\
\text { Pakistan } \\
\text { iii. World real per capita income } \\
\text { iv. Trade openness } \\
\text { v. Nominal Exchange rate for } \\
\text { Pakistan rupee against US } \\
\text { dollar }\end{array}$ & $\begin{array}{l}\text { Johansen and Juselius } \\
\text { methodology of } \\
\text { maximum likelihood } \\
\text { co-integration technique } \\
\text { to test long run } \\
\text { relationship }\end{array}$ & $\begin{array}{l}\text { Results show that } \\
\text { world income is the } \\
\text { major determinant of } \\
\text { export demand as it } \\
\text { shows high coefficient } \\
\text { of income for export } \\
\text { demand of textiles and } \\
\text { clothing sector. Trade } \\
\text { openness is second } \\
\text { major determinant } \\
\text { of export demand } \\
\text { (Pakistan). }\end{array}$ \\
\hline $\begin{array}{l}\text { Suhail P and } \\
\text { Sreejesh S (2011) }\end{array}$ & $\begin{array}{l}\text { Annual data from 1999-2007 for } \\
\text { the following variables } \\
\text { i. Export volume is used as } \\
\text { export demand. } \\
\text { ii. Price of exports of India and } \\
\text { Sri Lanka } \\
\text { iii. GDP } \\
\text { iv. Population } \\
\text { v. Dummy variable for the free } \\
\text { trade agreement between India } \\
\text { and Sri Lanka }\end{array}$ & $\begin{array}{l}\text { Multiple regression } \\
\text { model has been used for } \\
\text { the analysis }\end{array}$ & $\begin{array}{l}\text { It was evidenced } \\
\text { that the variables like } \\
\text { GDP and population } \\
\text { have positive and } \\
\text { significant coefficients } \\
\text { while the price is not a } \\
\text { significant determinant } \\
\text { of export of India and } \\
\text { Sri Lanka. }\end{array}$ \\
\hline
\end{tabular}




\begin{tabular}{|c|c|c|c|}
\hline $\begin{array}{l}\text { Tatre Jantarakolica } \\
\text { and Porjai } \\
\text { Chalermsook (2012) }\end{array}$ & $\begin{array}{l}\text { Quarterly data from } 2000 \text { Q1 to } \\
2011 \text { Q1 for the following } \\
\text { variables - } \\
\text { i. Thai's Export quantity index } \\
\text { ii. Weighted average of GDP of } \\
\text { importing counties } \\
\text { iii. Thai's export price index of } \\
\text { textiles and garments } \\
\text { iv. Exchange rate for Thai Baht } \\
\text { per US dollar }\end{array}$ & $\begin{array}{l}\text { Three models to } \\
\text { measure exchange rate } \\
\text { volatility- } \\
\text { i. Natural log of } \\
\text { quarterly variance } \\
\text { ii. Univariate GARCH } \\
\text { model } \\
\text { iii. Bivariate GARCH } \\
\text { model }\end{array}$ & $\begin{array}{l}\text { Export price index is } \\
\text { the factor that has } \\
\text { significant negative } \\
\text { impacts on export } \\
\text { quantity of textiles and } \\
\text { garment. } \\
\text { Exchange rate does } \\
\text { not directly influence } \\
\text { exports but its impacts } \\
\text { are caused through } \\
\text { the exchange rate } \\
\text { risk determined by } \\
\text { exchange rate volatility } \\
\text { The results confirm } \\
\text { that Thai textiles } \\
\text { and garments export } \\
\text { products are sensitive } \\
\text { to income; therefore } \\
\text { the income effect } \\
\text { turns out positively } \\
\text { significant. }\end{array}$ \\
\hline $\begin{array}{l}\text { Chee-Wooi Hooy } \\
\text { and Chee-Keong } \\
\text { Choong (2010) }\end{array}$ & $\begin{array}{l}\text { Monthly data from January } 1980 \\
\text { to January } 2010 \text { for the four } \\
\text { members of SAARC (Bangladesh, } \\
\text { India, Pakistan, Sri Lanka) for the } \\
\text { following variables- } \\
\text { i. Bilateral exports } \\
\text { ii. Income of trading partners } \\
\text { iii. Real Exchange rates } \\
\text { iv. Nominal exchange rate } \\
\text { volatility }\end{array}$ & $\begin{array}{l}\text { Multivariate asymmetric } \\
\text { CCC-GARCH model } \\
\text { and applied the bound } \\
\text { testing approach on the } \\
\text { standard trade model } \\
\text { framework }\end{array}$ & $\begin{array}{l}\text { The results showed } \\
\text { that the foreign } \\
\text { income, real exchange } \\
\text { rate and exchange } \\
\text { rate volatility does } \\
\text { affects exports in the } \\
\text { region. Further, it } \\
\text { was found that real } \\
\text { exchange rate volatility } \\
\text { have a significant and } \\
\text { negative impact on } \\
\text { the export demand of } \\
\text { most of the SAARC } \\
\text { countries. }\end{array}$ \\
\hline Choudhury (2001) & $\begin{array}{l}\text { Data on the following for the } \\
15 \text { trading partners of the } \\
\text { Bangladesh for the period } 1972 / 73 \\
\text { to } 1997 / 98 \\
\text { - Total exports and exports to } \\
\text { fifteen trading partners } \\
\text { - Export prices } \\
\text { - GDP }\end{array}$ & $\begin{array}{l}\text { Multiple regression } \\
\text { model has been used for } \\
\text { the analysis }\end{array}$ & $\begin{array}{l}\text { It is evidenced that } \\
\text { for small economies, } \\
\text { the devaluation of } \\
\text { local currency, does } \\
\text { not have a significant } \\
\text { impact on the demand } \\
\text { side of exports }\end{array}$ \\
\hline
\end{tabular}




\section{Appendix II : Data Definitions and Sources}

Quarterly data on world GDP, export and import values and GSP of Sri Lanka were obtained from IMF e-library for International Financial Statistics. Quarterly data relating to Sri Lanka's export volume index and REER 24 index were obtained from CBSL's Annual Reports (various years) and CBSL data bases. Details of the sources are given below.

\begin{tabular}{|c|c|c|}
\hline Variable & Definition & Source \\
\hline Indemand & $\begin{array}{l}\text { Export volume index for textiles and garments (in log) } \\
2010=100\end{array}$ & $\begin{array}{l}\text { Database of Central Bank of } \\
\text { Sri Lanka }\end{array}$ \\
\hline Inwgdp & Quarterly world GDP as a proxy for the income of buyers (in log) & $\begin{array}{l}\text { International Financial } \\
\text { Statistics,IMF }\end{array}$ \\
\hline Intopen & $\begin{array}{l}\% \text { of trade openness with rest of the world } \\
\text { [ (Value of exports + value of imports) / GDP] }{ }^{*} 100 \text { - on quarterly } \\
\text { basis (in log) }\end{array}$ & $\begin{array}{l}\text { International Financial } \\
\text { Statistics, IMF }\end{array}$ \\
\hline Inprice & Export price index for textiles and garments (in log) $2010=100$ & $\begin{array}{l}\text { Database of Central Bank of } \\
\text { Sri Lanka }\end{array}$ \\
\hline Inreer24 & Quarterly average REER index for 24 currency basket (in log) & $\begin{array}{l}\text { Database of Central Bank of } \\
\text { Sri Lanka }\end{array}$ \\
\hline$D 1$ & $\begin{array}{l}\text { Dummy variable to show facility of MFA/ATC and GSP+ Value } \\
1 \text { for the period } 1999 \text { Q1 to } 2004 \text { Q4 and again for the period } \\
2005 \text { Q2 to } 2009 \text { Q4 }\end{array}$ & \\
\hline$D 2$ & $\begin{array}{l}\text { Dummy variable to show the impact of global financial crisis and } \\
\text { debt crisis in the EU. Value } 1 \text { for the period } 2007 \text { Q2 to } 2009 \text { Q4 } \\
\text { and again for the period } 2010 \text { Q1 to } 2013 \text { Q1 }\end{array}$ & \\
\hline
\end{tabular}




\section{Appendix III : Robustness Check (Alternative Models)}

In order to check the robustness of the results following alternative models were analysed.

\begin{tabular}{|l|c|c|c|}
\hline \multicolumn{1}{|c|}{ Variable } & Model 1 & Model 2 & Model 3 \\
\hline Inwgdp & +0.3926 & +1.2991 & $(-8.5971)$ \\
\hline & $(-2.0836)$ & $(-5.1088)$ & \\
\hline Inreer24 & +0.9963 & & -0.6401 \\
\hline & $(-3.1828)$ & -0.2984 & $(7.5561)$ \\
\hline Intopen & -0.5498 & $(2.4947)$ & +0.1461 \\
\hline & $(3.0660)$ & & $(-3.6567)$ \\
\hline D1 & +0.2590 & +0.0346 \\
\hline & $(-3.9255)$ & +0.0708 & $(-1.1996)$ \\
\hline D2 & -0.1157 & $(-1.5716)$ & -0.7866 \\
\hline & $(1.3120)$ & -0.9612 & $(5.0624)$ \\
\hline Inprice & & $(4.1730)$ & 1.61236 \\
\hline & & 2.3164 & 0.9692 \\
\hline C & 1.4411 & 0.9594 & 32.7022 \\
\hline R Squared & 0.9538 & 90.2571 & \\
\hline F Statistics & 63.5483 & & \\
\hline
\end{tabular}

